Provided for non-commercial research and educational use only. Not for reproduction or distribution or commercial use.

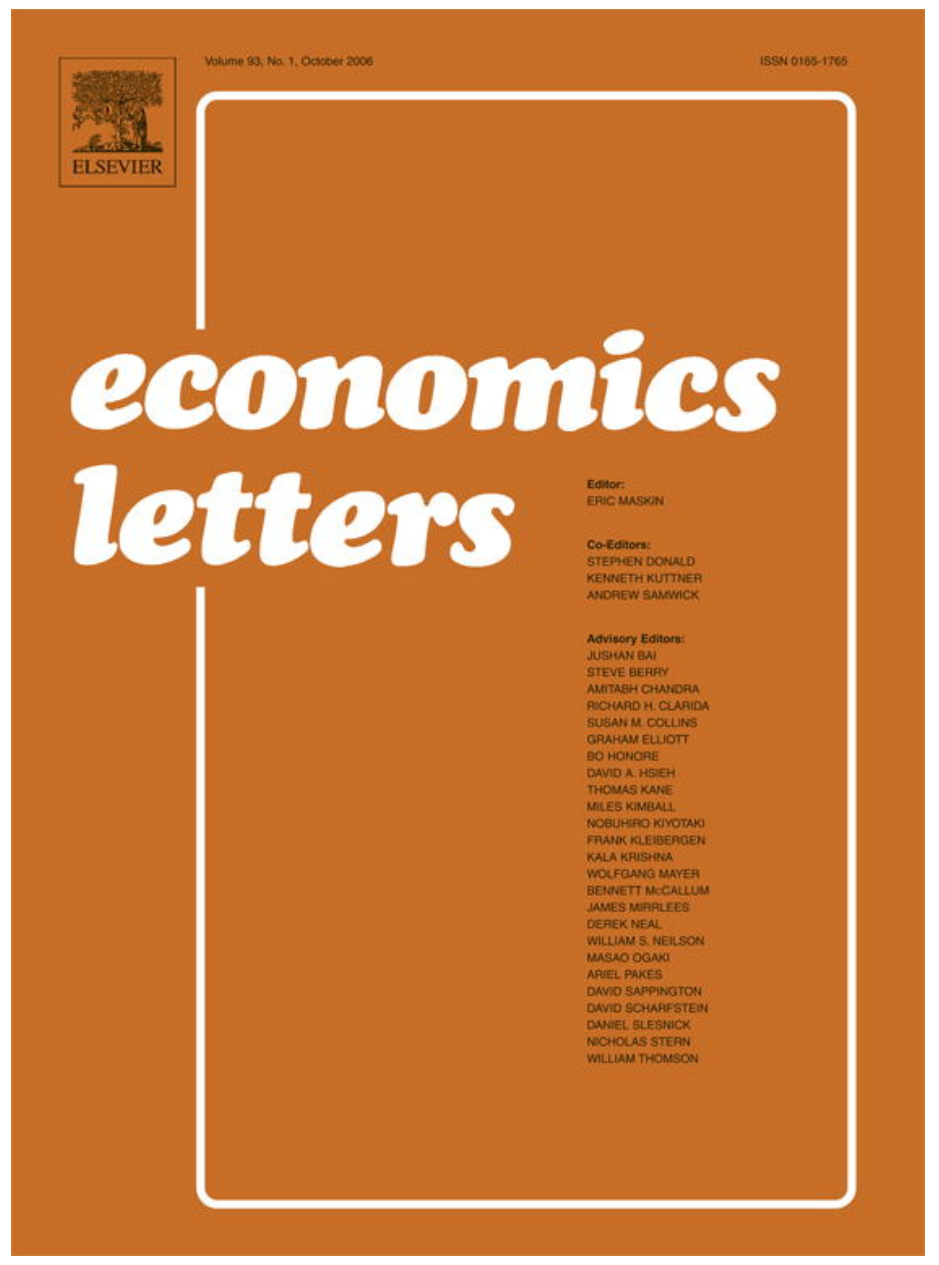

This article was originally published in a journal published by Elsevier, and the attached copy is provided by Elsevier for the author's benefit and for the benefit of the author's institution, for non-commercial research and educational use including without limitation use in instruction at your institution, sending it to specific colleagues that you know, and providing a copy to your institution's administrator.

All other uses, reproduction and distribution, including without limitation commercial reprints, selling or licensing copies or access,

or posting on open internet sites, your personal or institution's website or repository, are prohibited. For exceptions, permission may be sought for such use through Elsevier's permissions site at: 


\title{
Political business cycles in local employment: Evidence from Portugal
}

\author{
César Coelho ${ }^{\mathrm{a}}$, Francisco José Veiga ${ }^{\mathrm{b}}$, Linda G. Veiga ${ }^{\mathrm{b}, *}$ \\ a NIPE, Portugal \\ ${ }^{\mathrm{b}}$ Universidade do Minho and NIPE, Portugal
}

Received 29 July 2005; received in revised form 1 March 2006; accepted 28 March 2006

Available online 7 September 2006

\begin{abstract}
Using employment data for Portuguese municipalities, we find strong evidence of political business cycles. Employment increases shortly before elections mainly in municipalities where the mayor's party has a majority of deputies in the municipal assembly and where she is running for reelection.
\end{abstract}

(C) 2006 Elsevier B.V. All rights reserved.

Keywords: Political business cycles; Local governments; Employment; Portugal

JEL classification: D72; H7

\section{Introduction}

In this paper we test for the existence of political business cycles in employment in Portuguese municipalities. We use an unexplored dataset covering all mainland municipalities from 1985 to 2000. Our results provide strong evidence of employment increases before elections, particularly in municipalities where the mayor's party has a majority in the municipal assembly and where she is running for reelection. Employment increases are notably higher in construction and public works and in

\footnotetext{
* Corresponding author. Escola de Economia e Gestão, Universidade do Minho, 4710-057 Braga, Portugal. Tel.: +351 253604534; fax: +351253676375.

E-mail address: linda@eeg.uminho.pt (L.G. Veiga). 
community, social and personal services. We argue that these employment variations are a consequence of increases in local public expenditures that were documented by Veiga and Veiga (2004).

\section{Political business cycles in local employment}

Although the literature on political business cycles is already extensive, ${ }^{1}$ most studies focus on the behavior of central governments. However, Rogoff and Sibert (1988), Rogoff (1990) and Harrington (1993) have developed political business cycle models that are applicable to local as well as national governments. These models predict that incumbent politicians may increase spending prior to elections to signal greater "competence." This occurs when voters are rationally, but imperfectly, informed. In contrast, Nordhaus's (1975) well-known model of the political business cycle assumes that voters are myopically responsive to national economic conditions. Testing for the presence of local political business cycles may therefore help to distinguish the applicability of models that would have similar empirical implications at a national level.

In this paper, we use as our laboratory all the Portuguese mainland municipalities. In a previous paper, Veiga and Veiga (2004) provided strong evidence of opportunistic cycles in municipalities' expenditures, particularly in investment items highly visible to the electorate, such as those included in spending categories for Other Buildings and Miscellaneous Constructions (especially in Overpasses, streets and complementary works, Rural roads, and Others). Pre-election increases in these expenditures are consistent with an effort by mayors to signal greater competence. Building on these results, we now test for the existence of political business cycles in municipal employment.

The dependent variable in our analysis is the change in the number of employees working in the firms in the municipality ( $\Delta$ Employment). We are able to disaggregate this variable according to the Portuguese Standard Industrial Classification (CAE) system. Changes in national employment ( $\Delta$ National Employment) are used to control for the impact of the macroeconomic situation of the country. The set of political variables used consists of the following dummy variables:

- Election year (year before election): takes the value of 1 in election years (in the year before elections), and of zero otherwise;

- Right: equals one for municipalities run by right-wing mayors, and zero otherwise;

- Majority (minority): equals one for municipalities where the mayor's party has a majority (minority) in the Municipal Assembly, and zero otherwise;

- Incumbent: takes the value of 1 when the mayor is running for another term in office, and zero otherwise.

Three additional variables are included in all models as controls:

$-\%$ Pop $<15$ : percentage of the population under 15 years old;

$-\%$ Pop $>65$ : percentage of the population over 65 years old;

- PopDens: population density.

\footnotetext{
${ }^{1}$ For surveys of this literature see Alesina et al. (1997) and Drazen (2000).
} 
Table 1

Political business cycles in employment

\begin{tabular}{|c|c|c|c|c|c|}
\hline$\Delta$ Employment & 1 & 2 & 3 & 4 & 5 \\
\hline$\Delta$ Employment $(-1)$ & $-.131(-5.49)^{* *}$ & $-.133(-5.58)^{* *}$ & $-.130(-5.49)^{* *}$ & $-.131(-5.58)^{* *}$ & $-.131(-5.50)^{* *}$ \\
\hline$\Delta$ National Employment & $.245(4.74)^{* *}$ & $.320(5.19)^{* *}$ & $.243(4.73)^{* *}$ & $.237(4.49)^{* *}$ & $.245(4.74)^{* *}$ \\
\hline Election Year & $2.543(4.16)^{* *}$ & $3.477(5.14)^{* *}$ & & & \\
\hline Year Before Election & & $1.961(2.94)^{* *}$ & & & 2 \\
\hline Right & $2.010(3.58)^{* *}$ & $1.930(3.38)^{* *}$ & $1.661(2.75)^{* *}$ & $2.173(3.73)^{* *}$ & $2.006(3.59)^{* *}$ \\
\hline Election Year* Right & & & $3.497(3.59)^{* *}$ & & \\
\hline Election Year*Left & & & $1.808(2.26)^{*}$ & & \\
\hline Majority & & & & $.917(1.49)$ & \\
\hline Election Year* Majority & & & & $3.610(3.63)^{* *}$ & \\
\hline Election Year* Minority & & & & $1.326(1.64)$ & \\
\hline Election Year* Incumbent & & & & & $2.952(4.28)^{* *}$ \\
\hline Election Year* Not Incumbent & & & & & $.986(.69)$ \\
\hline \# Observations & 3847 & 3847 & 3847 & 3847 & 3847 \\
\hline \# Municipalities & 275 & 275 & 275 & 275 & 275 \\
\hline Sargan test ( $p$-value) & .308 & .294 & .322 & .314 & .298 \\
\hline
\end{tabular}

Sources: IMF(IFS), INE, MTSS and STAPE.

Estimations of system-GMM linear models for panel data (which combine the equations in first-differences with the equation in levels), using the econometric software Stata 8.2.

The coefficients and $t$-statistics for the control variables $\%$ Pop $<15, \% P o p>65$, and PopDens (included in all estimations) are not shown in order to economize space.

Two-step results using robust standard errors corrected for finite samples.

$T$-statistics are between parentheses. Significance level for which the null hypothesis is rejected: **, $1 \%$ and $*, 5 \%$.

Sargan is a test for the validity of the over-identifying restrictions for the GMM estimators, asymptotically $\chi^{2}$. $P$-value is reported. The hypothesis of no second-order serial correlation in the first-differenced residuals is never rejected.

Data on the total number of employees in municipal firms, and according to the Portuguese Standard Industrial Classification system, from 1985 to 2000, was obtained from the Quadros de Pessoal database, of the Portuguese Ministry of Labour and Social Solidarity (MTSS). ${ }^{2}$ Data on national employment comes from the IMF's International Financial Statistics. Political data, namely election dates and municipal electoral results were obtained from the Technical Staff for Matters Concerning the Electoral Process (STAPE). Finally, data on the three control variables was obtained from the Portuguese Institute of Statistics (INE).

It is worth noting that election dates are defined exogenously from the perspective of the local authorities and that, during our sample period, there were no legal restrictions on the number of terms a mayor could serve. In the period subsequent to the re-establishment of Democracy in Portugal in 1974, municipal elections have been held in December of 1976, 1979, 1982, 1985, 1989, 1993, 1997, 2001, and in October 2005.

The empirical model can be summarized as follows:

$$
y_{i t}=\alpha y_{i, t-1}+\boldsymbol{X}_{i, t}^{\prime} \boldsymbol{\beta}+v_{i}+\varepsilon_{i t} \quad i=1, \ldots, N \quad t=1, \ldots, T_{i}
$$

where $y_{i t}$ is the dependent variable ( $\Delta$ Employment), $\boldsymbol{X}_{i t}^{\prime}$ is a vector of explanatory variables (described above), $\boldsymbol{\beta}$ is a vector of parameters to be estimated, $v_{i}$ is the individual effect of municipality $i$, and $\varepsilon_{i t}$ is

${ }^{2}$ The Quadros de Pessoal are a yearly mandatory employment survey that covers virtually all firms employing paid labor in Portugal. 
Table 2

Political businees cycles in employment by economic activity

\begin{tabular}{|c|c|c|c|c|c|c|c|c|c|}
\hline & $\begin{array}{l}\text { CEA 1 } \\
\text { Agriculture, } \\
\text { Sylviculture, } \\
\text { Hunting and } \\
\text { Fisheries }\end{array}$ & $\begin{array}{l}\text { CEA } 2 \\
\text { Extractive } \\
\text { Industries }\end{array}$ & $\begin{array}{l}\text { CEA } 3 \\
\text { Transforming } \\
\text { Industries }\end{array}$ & $\begin{array}{l}\text { CEA } 4 \\
\text { Electricity, } \\
\text { Gas and } \\
\text { Water }\end{array}$ & $\begin{array}{l}\text { CEA } 5 \\
\text { Construction } \\
\text { and Public } \\
\text { Works }\end{array}$ & $\begin{array}{l}\text { CEA } 6 \\
\text { Commerce, } \\
\text { Restaurants } \\
\text { and Hotels }\end{array}$ & $\begin{array}{l}\text { CEA } 7 \\
\text { Transportation, } \\
\text { Storage and } \\
\text { Communications }\end{array}$ & $\begin{array}{l}\text { CEA } 8 \\
\text { Banks, Insurances, } \\
\text { Real Estate, } \\
\text { and Services } \\
\text { to Firms }\end{array}$ & $\begin{array}{l}\text { CEA } 9 \\
\text { Community, } \\
\text { Social, and } \\
\text { Personal Services }\end{array}$ \\
\hline Dep. Var. $(-1)$ & $\begin{array}{l}-.063 \\
(-4.06)^{* *}\end{array}$ & $\begin{array}{l}-.035 \\
(-4.61)^{* *}\end{array}$ & $\begin{array}{l}-.120 \\
(-6.99)^{* *}\end{array}$ & $\begin{array}{l}-.049 \\
(-3.57)^{* *}\end{array}$ & $\begin{array}{l}-.067 \\
(-3.70)^{* *}\end{array}$ & $\begin{array}{l}-.166 \\
(-7.35)^{* *}\end{array}$ & $\begin{array}{l}-.176 \\
(-2.94)^{* *}\end{array}$ & $\begin{array}{l}-.146 \\
(-5.26)^{* *}\end{array}$ & $\begin{array}{l}-.066 \\
(-4.19)^{* *}\end{array}$ \\
\hline $\begin{array}{l}\Delta \text { National } \\
\text { Employment }\end{array}$ & $\begin{array}{l}1.004 \\
(2.78)^{* *}\end{array}$ & $.591(0.98)$ & $.122(.70)$ & $.934(3.00)^{* *}$ & $1.243(4.56)^{* *}$ & $.001(.02)$ & $.875(4.00)^{* *}$ & $.352(2.52)^{*}$ & $1.504(5.32)^{* *}$ \\
\hline Election Year & $6.559(1.08)$ & $\begin{array}{l}19.569 \\
(2.19)^{*}\end{array}$ & $1.190(.74)$ & $\begin{array}{l}10.094 \\
(2.26)^{*}\end{array}$ & $\begin{array}{l}11.283 \\
(4.48)^{* *}\end{array}$ & $.818(1.00)$ & $\begin{array}{l}-4.489 \\
(-.97)\end{array}$ & $8.742(9.00)^{* *}$ & $15.155(5.24)^{* *}$ \\
\hline $\begin{array}{l}\text { Year Before } \\
\text { Election }\end{array}$ & & & & & $7.023(2.06$ & & & & $10.638(2.10)^{*}$ \\
\hline Right & $\begin{array}{l}-7.958 \\
(-1.41)\end{array}$ & $\begin{array}{l}-10.666 \\
(-0.90)\end{array}$ & $1.110(.97)$ & $\begin{array}{l}-9.746 \\
(-1.25)\end{array}$ & $4.114(1.86)^{*}$ & $\begin{array}{l}1.791 \\
(2.63)^{* *}\end{array}$ & $1.572(.61)$ & .994 (1.37) & $-2.935(-.83)$ \\
\hline \# Observations & 3690 & 2399 & 3844 & 3571 & 3782 & 3690 & 3844 & 3838 & 3828 \\
\hline \# Municipalities & 274 & 226 & 275 & 274 & 275 & 274 & 275 & 275 & 275 \\
\hline $\begin{array}{l}\text { Sargan test } \\
\text { ( } p \text {-value) }\end{array}$ & .238 & .835 & .478 & .165 & .342 & .238 & .221 & .194 & .072 \\
\hline
\end{tabular}

Sources: IMF(IFS), INE, MTSS and STAPE.

Estimations of system-GMM linear models for panel data (which combine the equations in first-differences with the equation in levels), using the econometric software Stata 8.2. Two-step results using robust standard errors corrected for finite samples.

The dependent variable is the percentage change in municipal employment for the classification of economic activity indicated in the respective column.

The coefficients and $t$-statistics for the control variables $\% P o p<15, \% P o p>65$, and PopDens (included in all estimations) are not shown in order to economize space. $T$-statistics are between parentheses. Significance level for which the null hypothesis is rejected: **, $1 \%$ and $*, 5 \%$.

Sargan is a test for the validity of the over-identifying restrictions for the GMM estimators, asymptotically $\chi^{2}$. $P$-value is reported. The hypothesis of no secondorder serial correlation in the first-differenced residuals is never rejected. 
the error term. Given the presence of individual effects, $v_{i}$, the model above can be estimated assuming those effects as fixed or random. But, the lagged value of the dependent variable would be correlated with the error term, $\varepsilon_{i t}$, even if the latter is not serially correlated. According to Arellano and Bond (1991), this implies inconsistent estimates of the model, when, as in our sample, there is a clear dominance of cross sections (275 municipalities) over time periods (16 years). These authors developed a Generalized Method of Moments (GMM) estimator that solves the problems noted above. First differencing (1) removes the individual effects $\left(v_{i}\right)$ and produces an equation that is estimable by instrumental variables. In this paper, we use the extended version of the GMM estimator proposed by Blundell and Bond (1998). ${ }^{3}$

Table 1 shows the results of estimations for changes in total municipal employment. In the first two columns, we can see that employment increases during electoral years (and the year before), relative to the remaining years of the electoral cycle, and that right-wing mayors increase local employment more than left-wing ones. Then, we tested for differences in opportunistic behavior according to ideology (column 3), the level of support the mayor enjoys at the Municipal Assembly (column 4), and the mayor's decision to run or not for another term in office (column 5). Results indicate that pre-election increases in local employment occur only when the mayor is running for reelection and when the mayor's party has a majority of deputies in the Municipal Assembly. In these circumstances mayors have both stronger incentives and greater power to manipulate spending. These effects are stronger in municipalities led by right-wing mayors.

When we perform the tests in employment series disaggregated by sector of activity (see Table 2), we find that employment increases in electoral years are stronger, and more significant, in Construction and Public Works and Community, Social and Personal Services. This result is not surprising if we take into account Veiga and Veiga's (2004) finding of strong evidence of opportunistic cycles in Portuguese municipalities' investment expenditures in Other Buildings, Miscellaneous Constructions and Other Investments. ${ }^{4}$

\section{Conclusion}

Using an unexplored dataset describing employment in all mainland Portuguese municipalities over a period of 16 years, we provide strong evidence of political business cycles in local employment. ${ }^{5}$ Although mayors do not control a large fraction of local employment directly, they affect it indirectly through municipal expenditures that generate jobs in local firms. By improving local economic conditions shortly before elections, mayors may signal their competence to the electorate and improve their chances of reelection, consistent with the rational political business cycle models introduced by Rogoff and Sibert (1988).

\footnotetext{
${ }^{3}$ Difference Sargan tests indicate that, for our data, this system-GMM estimator, which combines the first-differenced equations with the equation in levels, is preferable to that of Arellano and Bond (1991), which only includes the first-differenced equations. In all estimations, the instruments used for the lagged dependent variable were the following: levels lagged 2 and 3 periods were used in the equations in first differences, and once lagged first differences were used in the equation in levels. Since the remaining explanatory variables are exogenous, they were used as their own instruments.

${ }^{4}$ On these series there are increases in the election year, relative to the sample mean, of $14.9 \%, 10.4 \%$ and $21.7 \%$, respectively.

5 It is worth noting that results are basically the same when we use employment levels (employment as a percentage of municipal population) instead of changes in employment. These results are available from the authors upon request.
} 


\section{Acknowledgements}

We acknowledge helpful comments from Henry Chappell. Financial support was provided by the Portuguese Foundation for Science and Technology under research grants POCTI/2001/ECO/37457 and POCI/EGE/58641/2004 (partially funded by FEDER).

\section{References}

Alesina, A., Cohen, G., Roubini, N., 1997. Political Cycles and the Macroeconomy. MIT Press, Cambridge, MA.

Arellano, M., Bond, S., 1991. Some tests of specification for panel data: Monte Carlo evidence and an application to employment equations. Review of Economic Studies 58, 277-297.

Blundell, R., Bond, S., 1998. Initial conditions and moment restrictions in dynamic panel data models. Journal of Econometrics $87,115-143$.

Drazen, A., 2000. Political Economy in Macroeconomics. Princeton University Press, New Jersey, NJ.

Harrington Jr., J., 1993. Economic policy, economic performance, and elections. American Economic Review 83 (1), $27-42$. Nordhaus, W., 1975. The Political Business Cycle. Review of Economic Studies 42, 169-190.

Rogoff, K., 1990. Equilibrium political budget cycles. American Economic Review 80, $21-36$.

Rogoff, K., Sibert, A., 1988. Elections and Macroeconomic Policy Cycles. Review of Economic Studies 55, $1-16$.

Veiga, L.G., Veiga, F.J., 2004. Political Business Cycles at the Municipal Level, NIPE Working Paper, WP-4/2004, 1-26. Available in PDF format at: http://www.eeg.uminho.pt/economia/nipe/WP/WP_NIPE_4_04.pdf. 